\title{
Koncepcja local content w systemie zamówień publicznych
}

\author{
El concepto de "local content" \\ en el sistema de contratación pública
}

Jarosław Kola

Uniwersytet im. Adama Mickiewicza w Poznaniu

\section{Wprowadzenie}

Zamówienia publiczne powinny odgrywać kluczową rolę w realizacji strategicznych celów polityki rozwoju jako jeden z instrumentów rynkowych wykorzystywanych w celu osiągnięcia inteligentnego, trwałego wzrostu gospodarczego sprzyjającego włączeniu społecznemu, przy jednoczesnym zagwarantowaniu najbardziej efektywnego wykorzystania środków publicznych. W ten sposób funkcje prawa zamówień publicznych scharakteryzowano w preambułach unijnych dyrektyw regulujących zasady udzielania zamówień w Unii Europejskiej ${ }^{1}$. Wskazano w nich, że wysiłki państw członkowskich na rzecz zwiększania efektywności wydatków publicznych powinny polegać w szczególności na wzmacnianiu udziału małych i średnich przedsiębiorstw (MŚP) w rynku zamówień publicznych, a także na wprzęganiu inwestycji publicznych w proces realizacji celów społecznych. Działania podejmowane w odniesieniu do prawa zamówień publicznych - zarówno na poziomie Unii Europejskiej, jak i poszczególnych państw członkowskich - potwierdzają, że paradygmat udzielania zamówień ulega obecnie istotnej przemianie. Prawo zamówień coraz częściej jest postrzegane nie tylko jako zbiór instrumentów zakupowych, ale również jako użyteczny instrument realizacji celów strategicznych państw i poszczególnych zamawiających. Dlatego system zamówień publicznych oraz normy prawne regulujące jego funkcjonowanie są niezwykle inspirującym obszarem badań podejmowanych w ramach dyskusji nad problematyką strategicznych celów polityki rozwoju.

${ }^{1}$ Zob. motyw 2 preambuły dyrektywy Parlamentu Europejskiego i Rady 2014/24/UE z dnia 26 lutego 2014 r. w sprawie zamówień publicznych, uchylającej dyrektywę 2004/18/WE; motyw 3 preambuły dyrektywy Parlamentu Europejskiego i Rady 2014/23/UE z dnia 26 lutego 2014 r. w sprawie udzielania koncesji, a także motyw 4 preambuły dyrektywy Parlamentu Europejskiego i Rady 2014/25/UE z dnia 26 lutego 2014 r. w sprawie udzielania zamówień przez podmioty działające w sektorach gospodarki wodnej, energetyki, transportu i usług pocztowych, uchylającej dyrektywę 2004/17/WE, Dz. Urz. UE L 94/243. 
Z perspektywy Unii Europejskiej oraz jej państw członkowskich szczególne znaczenie mają obecnie cele formułowane $\mathrm{w}$ odniesieniu do rozwoju jednolitego rynku cyfrowego i innowacji, a także związane z działaniami na rzecz ochrony klimatu i transformacji energetycznej. Zarazem aktualne pozostają postulaty dotyczące wspierania MŚP poprzez system zamówień publicznych oraz wykorzystywania go do wzmacniania potencjału krajowych gospodarek. Wreszcie coraz wyraźniej jest dostrzegana konieczność zapewniania spójności działań podejmowanych na rzecz realizacji strategicznych celów polityki rozwoju, a także potrzeba osiągania synergii poprzez realizację inwestycji publicznych w sposób zapewniający nie tylko bezpośrednią korzyść ekonomiczną inwestorów, ale również zrealizowanie tzw. drugoplanowych celów społecznych, ekologicznych, innowacyjnych itp. W tym kontekście warto postawić następujące pytania: Czy realizacja wszystkich wspomnianych postulatów jest w ogóle możliwa? Czy w świetle obowiązujących regulacji możliwe jest zorganizowanie postępowania o udzielenie zamówienia publicznego w taki sposób, który będzie odpowiadał na wyzwania związane z procesem „uinnowacyjniania" unijnej gospodarki oraz transformacją energetyczną, a jednocześnie pozwoli na realizację strategicznego celu wspierania MŚP? Przedstawione w kolejnych akapitach rozważania potwierdzają hipotezę, że na tak postawione pytania należy udzielić odpowiedzi pozytywnej, a jednym z rozwiązań temu służących jest realizacja koncepcji local content $\mathrm{w}$ ramach działalności inwestycyjnej podmiotów publicznych.

\section{Koncepcja local content}

Termin local content jest zapożyczeniem z języka angielskiego, które w ostatnim czasie - w takiej właśnie obcojęzycznej formie - jest używane również w prowadzonej w Polsce debacie na temat oczekiwanych kierunków prowadzenia inwestycji realizujących strategiczne cele polityki rozwoju związane z transformację energetyczną ${ }^{2}$. Pojęcie to jest trudne do zdefiniowania, choć oczywiście próby jego syntetycznego charakteryzowania były już w literaturze podejmowane ${ }^{3}$. Na ich podstawie

${ }^{2}$ Zob. np. komunikat opublikowany 15 stycznia 2020 r. na stronie internetowej Ministerstwa Aktywów Państwowych: Projekt ustawy o promowaniu wytwarzania energii elektrycznej w morskich farmach wiatrowych przekazany do konsultacji, https://www.gov.pl/web/aktywa-panstwowe/projekt-ustawy-o-promowaniu-wytwarzania-energii-elektrycznej-w-morskich-farmach-wiatrowych-przekazany-do-konsultacji [dostęp: 1.05.2021]; A. Kornecka, Nowe farmy wiatrowe to impuls dla rozwoju gospodarczego, „Rzeczpospolita”, 21 kwietnia 2021 r., https://www.rp.pl/Opinie/304219898-Anna-Kornecka-Nowe-farmy-wiatrowe-to-impuls-dla-rozwoju-gospodarczego.html [dostęp: 1.05.2021].

${ }^{3}$ Zob. np. Ch. Nwapi, Defining the "Local" in Local Content Requirements in the Oil and Gas and Mining Sectors in Developing Countries, „Law and Development Review” 2015, vol. 8, nr 1, s. 187-216; J. Korinek, I. Ramdoo, Local content policies in mineral-exporting countries, OECD Trade Policy Papers nr 209/2017, s. 12; H. Deringer, F. Erixon, Ph. Lamprecht, E. van der Marel, The Economic Impact of Local Content Requirements: A Case Study of Heavy Vehicles, ECIPE Occasional Paper nr 1/2018, s. 3-5. 
można opisać koncepcję local content poprzez wskazanie kluczowych jej założeń. Po pierwsze wyraża ona dążenie do promowania świadczeń oferowanych przez przedsiębiorców działających w regionie lub państwie nabywcy. W opracowaniach OECD koncepcja local content jest ujmowana jako wyraz polityki ukierunkowanej na preferowanie rozwiązań oferowanych przez przemysł krajowy w stosunku do konkurentów zagranicznych, w szczególności poprzez skłanianie jednostek organizacyjnych władzy publicznej do nabywania krajowych dóbr i usług ${ }^{4}$. Zwykle tego rodzaju rozwiązania są stosowane w państwach o dynamicznym wzroście gospodarczym, które zarazem są zaliczane do tzw. rynków wschodzących lub nowo uprzemysłowionych, jak choćby tzw. państwa BRICS czy wiele państw Afryki ${ }^{5}$.

Preferencyjne traktowanie lokalnych przedsiębiorców w postępowaniach o udzielenie zamówienia publicznego może przybierać różne formy. Wśród przykładów wymienia się m.in. zobowiązywanie przedsiębiorców do wykorzystywania krajowych dóbr i usług w łańcuchach dostaw na odpowiednim poziomie czy też zachęty (np. podatkowe) dla przedsiębiorców, którzy prowadzą działalność wytwórczą w danym państwie lub nawiązują współpracę z lokalnymi przedsiębiorcami na odpowiednim poziomie ${ }^{6}$, co zakładano np. w brazylijskim programie „Inovar Auto”jednym z najbardziej znanych tego typu programów na świecie ${ }^{7}$. Co ważne, możliwość realizacji założeń koncepcji local content nie jest zarezerwowana wyłącznie dla władzy publicznej. Oczywiście ustanawianie zachęt podatkowych i normowanie stosunków gospodarczych jest kompetencją jej upoważnionych organów, niemniej podmioty nienależące do struktury administracyjnej państw także mogą wyznaczać i realizować cele oparte na koncepcji local content. Szczególnie do tego predystynowane są instrumenty zakupowe, które pozwalają stymulować oczekiwane zjawiska w ramach prowadzonych postępowań inwestycyjnych. Warto podkreślić, że dotyczy to zarówno podmiotów prywatnych, jak również podmiotów, których swoboda kontraktowa jest istotnie ograniczona przepisami prawa zamówień publicznych.

W okresie dynamicznych przemian gospodarczych czy politycznych państwa decydują się czasami na wyposażenie zamawiających w niezwykle protekcjonistyczne i restrykcyjne rozwiązania. Niewątpliwie należą do nich tzw. preferencje krajowe, których stosowanie może oznaczać wyłączenie możliwości udziału podmiotów

${ }^{4}$ OECD, Local Content Requirements, Trade Policy Brief February 2019, s. 1: „Local content requirements (LCRs) are part of a broader set of 'localisation' policies that favour domestic industry over foreign competition, requiring companies and the government to use domestically-produced goods or services as inputs".

${ }^{5}$ Zob. United Nations Conference on Trade and Development [UNCTAD], Local Content Requirements and the Green Economy, United Nations Conference on Trade and Development, Geneva 2014. Zob. także J.S. Ovadia, The Role of Local Content Policies in Natural Resources-based Development, Österreichische Forschungsstiftung für Internationale Entwicklung. Rohstoffe und Entwicklung, Wien 2015, s. 37-45.

${ }^{6}$ Zob. H. Deringer, F. Erixon, Ph. Lamprecht, E. van der Marel, dz. cyt.

${ }^{7}$ Zob. np. T. Sturgeon, L. Lima Chagas, J. Barnes, Inovar Auto: Evaluating Brazil's Automative Industrial Policy to Meet the Challenges of Global Value Chains, World Bank, Washington, D.C., 2017. 
zagranicznych w postępowaniach o udzielenie zamówienia w danym kraju. Tytułem przykładu warto wskazać, że tego rodzaju rozwiązanie jest znane w polskim systemie prawnym. W przepisach regulujących udzielanie zamówień publicznych (rządowych) przed II wojną światową ustawodawca ustanowił obowiązek dążenia, by zamówienia były realizowane przez wykonawców prowadzących swą działalność w kraju oraz „przy użyciu sił krajowych i surowców oraz wszelkich wyrobów po-

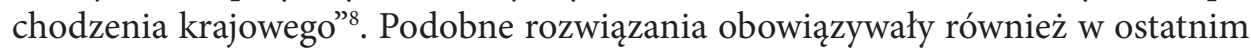
trzydziestoleciu, jeszcze przed przystąpieniem Polski do Unii Europejskiej. Do tego momentu obowiązywały przepisy, na podstawie których zmawiający mogli zastrzec możliwość udziału w postępowaniu o udzielenie niektórych zamówień wyłącznie dla przedsiębiorców krajowych oraz zagranicznych mających oddział lub przedstawicielstwo w Polsce. Mogli również wymagać, aby całość prac objętych zamówieniem obejmującym usługi lub roboty budowlane realizowane na obszarze Polski była wykonywana przy wykorzystaniu podmiotów, surowców i produktów krajowych ${ }^{9}$.

Obecnie stosowanie rozwiązań tak istotnie ingerujących w obrót gospodarczy i ograniczających swobodny przepływ towarów i usług w ramach Unii Europejskiej jest oczywiście niedozwolone. W związku z tym warto postawić zasadnicze pytanie: Czy - i ewentualnie w jakim zakresie - realizacja koncepcji local content poprzez udzielanie zamówień publicznych jest możliwa w świetle obowiązujących przepisów prawa unijnego? Jest ono szczególnie istotne, biorąc pod uwagę, że w ostatnich latach można zaobserwować rosnące zainteresowanie koncepcją local content zarówno w państwach członkowskich UE, jak i poza nią. Szczególnie widoczne jest to w sektorze energetycznym. Tytułem przykładu można wskazać Wielką Brytanię, gdzie jeszcze przed wystąpieniem z Unii Europejskiej podejmowano działania na rzecz wypracowania instrumentów służących realizacji tej koncepcji ${ }^{10} \mathrm{w}$ odniesieniu do przedsięwzięć z zakresu morskiej energetyki wiatrowej ${ }^{11}$. Podobne działania w tym obszarze podejmowane są również - a może przede wszystkim - poza Unią Europejską i Europą, co może być źródłem inspirujących doświadczeń ${ }^{12}$. Z innej jednak strony instytucje UE wyrażają wobec podstawowych założeń koncepcji local content krytyczne stanowisko, postrzegając je jako barierę lub ograniczenie handlu.

${ }^{8}$ Zob. art. 2 ust. 1 i 2 ustawy z dnia 15 lutego 1933 r. o dostawach i robotach na rzecz Skarbu Państwa, samorządu oraz instytucyj prawa publicznego, Dz. U. 1933 nr 19 poz. 127.

${ }^{9}$ Art. 18 ust. 2-3 ustawy z dnia 10 czerwca 1994 r. o zamówieniach publicznych, Dz. U. 1994 nr 76 poz. 344 .

${ }^{10} \mathrm{Na}$ ten temat zob. np. A. Roberts, B. Valpy, Methodology for Measuring the UK Content of UK Offshore Wind Farms, BVG Associates 2015, https://bvgassociates.com/publications/methodology-for-measuring-uk-content-for-uk-offshore-wind-farms-may-2015-cover-2/ [dostęp: 15.05.2021].

${ }^{11}$ Industrial Strategy. Offshore Wind Sector Deal, 2019, https://www.gov.uk/government/publications/ offshore-wind-sector-deal [dostęp: 15.05.2021].

12 Zob. np. K.-H. Chien, Pacing for Renewable Energy Development: The Developmental State in Taiwan's Offshore Wind Power, „Annals of the American Association of Geographers” 2020, vol. 110, iss. 3, pp. 793-807, wraz z przywołaną tam literaturą. 
Mianowicie Komisja Europejska krytycznie ocenia wszelkie przejawy preferencji czy barier dla handlu i inwestycji, włączając w to koncepcję local content, w szczególności poprzez stosowanie jej klasycznych instrumentów, do których można zaliczyć formułowanie wymogów stosowania materiałów miejscowego pochodzenia. W tym kontekście stwierdza się, że „W wymogach stosowania materiałów miejscowego pochodzenia zobowiązuje się przedsiębiorstwa zagraniczne do korzystania z określonej ilości lokalnie wyprodukowanych towarów lub lokalnie świadczonych usług. Wymogi stosowania materiałów miejscowego pochodzenia są częścią wielu rodzajów barier i mają wpływ na np. pożyczki preferencyjne, zamówienia publiczne lub warunki wpływające na bezpośrednie inwestycje zagraniczne. [...] Wymaga to od UE uważnego skupienia się na tych praktykach"13.

Przede wszystkim należy jednak wskazać, że niemal trzydzieści lat temu w orzecznictwie wspólnotowym jednoznacznie opowiedziano się za niedopuszczalnością realizowania koncepcji local content w modelu najbardziej restrykcyjnym, tj. zakładającym ustanawianie kategorycznego wymogu wykorzystywania dóbr krajowych przy realizacji zamówień publicznych. Takie stanowisko wyrażono w wyroku z dnia 22 czerwca 1993 r. ws. C-243/89 Komisja Europejska przeciwko Królestwu Danii, który dotyczył tzw. klauzuli Danish content. Poprzez jej stosowanie duński zamawiający Aktieselskabet Storeboeltsforbindelsen, udzielając zamówienia publicznego, zobowiązywał wykonawców wprost do maksymalnego wykorzystywania „duńskich zasobów” ${ }^{14}$. Z pozoru mogłoby się wydawać, że wobec istnienia takiego orzeczenia wszelkie próby realizowania koncepcji local content są skazane na niepowodzenie i należałoby w odniesieniu do nich a priori przesądzać o niezgodności z prawem unijnym. Założenie takie nie powinno być jednak przyjmowane automatycznie z kilku powodów.

Po pierwsze przywołane orzeczenie było wydane w okolicznościach, w których jeszcze przed wydaniem rozstrzygnięcia w konkretnym kwestionowanym postępowaniu o udzielenie zamówienia zrezygnowano ze stosowania klauzuli Danish content, a duński rząd nie podjął próby obrony dopuszczalności jej stosowania. Tym samym w orzeczeniu w istocie nie podjęto refleksji nad fundamentalnym pytaniem o generalną dopuszczalność realizowania koncepcji local content w jakimkolwiek zakresie. Po drugie, oczywiście w świetle ówczesnego orzecznictwa, prawdopodobne wydaje się, że nawet na generalne pytanie Trybunał na początku lat dziewięćdziesiątych udzieliłby odpowiedzi negatywnej. Warto jednak nadmienić, że od tego czasu orzecznictwo w sprawach z zakresu prawa zamówień publicznych wyewoluowało w kierunku zasadniczej dopuszczalności uwzględniania tzw. celów drugoplanowych, a więc w szczególności udzielania zamówień w sposób ukierunkowany na realizację

${ }^{13}$ Sprawozdanie Komisji dla Parlamentu Europejskiego i Rady w sprawie barier w handlu i inwestycjach, COM/2020/236 final.

${ }^{14}$ Tzw. klauzuli „Danish content” nadano następujące brzmienie: „The contractor is obliged to use to the greatest possible extent Danish materials, consumer goods, labour and equipment". 
strategicznych celów polityki rozwoju, w tym wspierania MŚP. Co więcej, ewolucja ta skłoniła również prawodawcę unijnego do zmiany unijnego prawa zamówień publicznych polegającej na wyraźnym zaaprobowaniu strategicznego wykorzystywania zamówień (strategic use of public procurement) oraz na rozbudowaniu instrumentarium prawnego umożliwiającego stosowanie prawa zamówień publicznych w tym paradygmacie. Uprawnione jest więc stwierdzenie, że o ile ustanawianie wyraźnych preferencji krajowych byłoby zapewne również obecnie uznane przez TSUE za niedopuszczalne, o tyle wprzęganie systemu zamówień publicznych w realizację celów strategicznych, obejmujących wspieranie krajowych/lokalnych MŚP, należy uznawać za co najmniej niewykluczone, oczywiście z poszanowaniem ogólnych zasad unijnego prawa zamówień publicznych, w szczególności zasady proporcjonalności. To zaś skłania, by nie stawiać już pytania o to, czy w ogóle możliwe jest realizowanie koncepcji local content przy udzielaniu zamówień publicznych, lecz podejmować refleksję nad dopuszczalnym zakresem takiego działania.

W każdym razie, biorąc pod uwagę dotychczasowe rozważania ${ }^{15}$, odpowiedź na pytanie o dopuszczalność realizacji celów koncepcji local content poprzez udzielanie zamówień publicznych może wywoływać wątpliwości. Przy tym pytanie to nie ma jedynie teoretycznego znaczenia, lecz warto stawiać je ze względu na dużą doniosłość praktyczną wobec coraz wyraźniejszych deklaracji wprzęgania systemu zamówień publicznych $\mathrm{w}$ proces realizacji strategicznych celów polityki rozwoju, $\mathrm{w}$ tym dotyczących rozwoju krajowych MŚP. Czy zatem instrumentem ich realizacji mogą być zamówienia publiczne udzielane w postępowaniach realizujących założenia koncepcji local content? Na tak postawione pytanie należy udzielić odpowiedzi pozytywnej. Zastrzec jednak należy, że realizacja tych założeń musi się odbywać w ramach wyznaczonych podstawowymi zasadami unijnego prawa zamówień publicznych, którymi są równe traktowanie wszystkich wykonawców i uczciwa konkurencja.

\section{Granice instrumentalizacji zamówień publicznych w prawie UE}

Przede wszystkim należy zaznaczyć, że wykorzystywanie zamówień publicznych dla osiągania celów innych niż tylko bezpośrednia korzyść ekonomiczna zamawiającego (tzw. celów drugoplanowych ${ }^{16}$ ) nie jest sama w sobie niezgodna z prawem unijnym. Wprost przeciwnie - co najmniej od początku XXI wieku w literaturze jest prowadzona ożywiona dyskusja nad potencjałem systemu zamówień publicz-

${ }^{15}$ Jak wskazuje się w orzecznictwie, Polska, „podpisując Układ Europejski, zobowiązała się dostosowywać swe prawo do standardów europejskich, a dostosowanie to nie polega tylko na dostosowaniu litery prawa, lecz na harmonizacji standardu zachowań prawnych, co obejmuje sobą także praktykę stosowania i interpretacji prawa" - wyrok WSA w Warszawie z dnia 23 maja 2017 r., sygn. V SA/Wa 1597/16.

${ }_{16}$ Zob. przede wszystkim Ch. Benedict, Sekundärzwecke im Vergabeverfahren, Heidelberg 2000. 
nych w zakresie realizacji strategicznych celów polityki rozwoju. W jej ramach coraz powszechniejsze staje się podejście, wedle którego instrumentalizacja prawa zamówień publicznych oraz poszczególnych zamówien - a więc ich wykorzystywanie dla osiągania tzw. celów drugoplanowych - jest nie tylko akceptowana, ale wręcz zasadniczo aprobowana ${ }^{17}$. Wreszcie w uchwalonych w 2014 r. unijnych dyrektywach normujących udzielanie zamówień publicznych przypisano im kluczową rolę w realizacji celów unijnej Strategii na rzecz inteligentnego i zrównoważonego rozwoju sprzyjającego włączeniu społecznemu „Europa 2020”, która w szczególności obejmuje wspieranie MŚP ${ }^{18}$.

Zanim jednak dopuszczalność instrumentalizacji zamówień publicznych została tak jednoznacznie potwierdzona w systemie prawnym UE, jej granice były wytyczane $w$ unijnym orzecznictwie. Podstawowe znaczenie miał w tym kontekście wyrok z dnia 17 września 2002 r. w sprawie C-513/99 Concordia Bus Finland Oy Ab przeciwko Miastu Helsinki oraz HKL-Bussiliikenne. Spór dotyczył postępowania o udzielenie zamówienia publicznego na obsługę sieci autobusów miejskich w mieście Helsinki, w którym oferta najkorzystniejsza ekonomicznie miała zostać wybrana z uwzględnieniem trzech kategorii kryteriów, którymi były: łączna cena żądana za eksploatację, jakość sprzętu (autobusów) ${ }^{19}$ oraz związane

${ }^{17} \mathrm{Na}$ ten temat zob. w szczególności Ch. Benedict, dz. cyt.; A. Sołtysińska, Instrumentalizacja zamówień publicznych - rozważania na tle unormowań prawa wspólnotowego, w: Studia z prawa Unii Europejskiej, red. S. Biernat, Kraków 2000, s. 373-385; Ch. McCrudden, Buying Social Justice: Equality, Government Procurement, \& Legal Change, Oxford 2007; K. Horubski, Instrumentalizacja kryteriów oceny ofert, „Przegląd Prawa Publicznego" 2007, nr 11, s. 24 i nast.; Social and Environmental Policies in EC Procurement Law. New Directives and New Directions, red. S. Arrowsmith, P. Kunzlik, Cambridge 2009; The Law of Green and Social Procurement in Europe, red. R. Caranta, M. Trybus, Copenhagen 2010; J. Hettne, Strategic Use of Public Procurement - Limits and Opportunities, „European Policy Analysis” 2013, nr 7, s. 1-20; M. Szydło, Prawna koncepcja zamówienia publicznego, Warszawa 2014, s. 19 i nast. wraz z cytowaną tam literaturą; Sustainable Public Procurement under EU Law: New Perspectives on the State as Stakeholder, red. B. Sjåfjell, A. Wiesbrock, Cambridge 2015; M. Stawiński, Instrumentalizacja prawa zamówień publicznych w Unii Europejskiej w kontekście kryteriów oceny ofert, „Acta Universitatis Wratislaviensis - Przegląd Prawa i Administracji” 2016, t. 105 s. 159-172; J. Kola, Public Procurement as a Tool of Conducting Development Policy in Emerging Markets: The Example of Poland, w: Public Procurement Regulation in Africa: Development in Uncertain Times, red. G. Quinot, S. Williams-Elegbe, Durban - Johannesburg - Cape Town 2020, s. 249-269.

${ }^{18}$ Motyw 2 preambuły dyrektywy Parlamentu Europejskiego i Rady 2014/24/UE z 26.2.2014 r. w sprawie zamówień publicznych, uchylającej dyrektywę 2004/18/WE; motyw 4 preambuły dyrektywy Parlamentu Europejskiego i Rady 2014/25/UE z 26.2.2014 r. w sprawie udzielania zamówień przez podmioty działające w sektorach gospodarki wodnej, energetyki, transportu i usług pocztowych, uchylającej dyrektywę 2004/17/ WE; także motyw 3 preambuły dyrektywy Parlamentu Europejskiego i Rady 2014/23/UE z 26.2.2014 r. w sprawie udzielania koncesji.

${ }^{19}$ Wyrok Trybunału z dnia 17 września 2002 r. w sprawie C-513/99 Concordia Bus Finland Oy Ab, uprzednio Stagecoach Finland Oy Ab przeciwko Helsingin kaupunki i HKL-Bussiliikenne, motyw 23: „oferent mógł uzyskać maksymalnie 10 dodatkowych punktów na podstawie określonych kryteriów. I tak punkty takie były przyznawane w szczególności za wykorzystanie autobusów, których po pierwsze emisja tlenku azotu była niższa niż $4 \mathrm{~g} / \mathrm{kWh}(+2,5$ punktu/autobus) lub niższa niż $2 \mathrm{~g} / \mathrm{kWh}(+3,5$ punktu/autobus $)$, oraz po drugie, których poziom hałasu był niższy niż $77 \mathrm{~dB}$ (+1 punkt/autobus)". 
z jego eksploatacją parametry wpływające na jakość środowiska naturalnego ${ }^{20}$. Taki model wyboru oferty najkorzystniejszej został zakwestionowany przez Concordia Bus Finland Oy Ab, która podważała dopuszczalność stosowania kryteriów ekologicznych, wskazując, że kryteria te „nie mają żadnego bezpośredniego związku z przedmiotem zamówienia" ${ }^{21}$. W odpowiedzi na stawiane zarzuty miasto Helsinki i rząd fiński argumentowały, że „w interesie tego miasta i jego mieszkańców leży, aby szkodliwe emisje zostały ograniczone w możliwie największym stopniu. Dla miasta Helsinki, które jest odpowiedzialne za ochronę środowiska naturalnego na jego terytorium, wynikają stąd bowiem bezpośrednie oszczędności, w szczególności w sektorze medyczno-socjalnym, który stanowi łącznie około 50\% jego budżetu"22. Tym samym miasto Helsinki przyjęło stanowisko, wedle którego potrzeby zaspokajane poprzez udzielenie zamówienia publicznego nie muszą mieć charakteru czysto ekonomicznego, a zamawiający ma swobodę w kształtowaniu modelu wyboru najkorzystniejszej oferty w ramach wyznaczonych podstawowymi zasadami unijnego prawa zamówień publicznych, którymi są w szczególności przejrzystość, proporcjonalność i obiektywny charakter stawianych wymagań.

Ostatecznie za takim właśnie podejściem opowiedział się Trybunał. Wskazał mianowicie, że przepisów prawa unijnego „nie można interpretować w ten sposób, że każde z kryteriów udzielenia zamówienia przyjętych przez zamawiającego w celu zidentyfikowania oferty najkorzystniejszej ekonomicznie musi koniecznie mieć charakter czysto ekonomiczny. Nie można bowiem wykluczyć, że czynniki, które nie są czysto ekonomiczne, mogą mieć wpływ na ofertę z punktu widzenia tego zamawiającego. Potwierdza to również samo brzmienie tego przepisu, który wyraźnie odwołuje się do kryterium dotyczącego estetyki oferty"23. W cytowanym orzeczeniu potwierdzono, że wszelkie działania zamawiających - $\mathrm{w}$ tym dotyczące kryteriów oceny ofert - powinny zapewniać uczciwą konkurencję pomiędzy wszystkimi wykonawcami, a także realizować unijne zasady przejrzystości, proporcjonalności i obiektywizmu, lecz jednocześnie „zasada równego traktowania nie sprzeciwia się kryteriom związanym z ochroną środowiska naturalnego, takim jak te sporne w sprawie przed sądem krajowym, z tego tylko względu, że przedsiębiorstwo transportowe należące do instytucji zamawiającej jest jednym $\mathrm{z}$ nielicznych przedsiębiorstw, które mają możliwość zaoferowania sprzętu spełniającego te kryteria"24.

W podobny sposób rozstrzygnięto spór w sprawie C-448/01 EVN AG i Wienstrom GmbH przeciwko Republice Austrii. W wyroku z dnia 4 grudnia 2003 r.

${ }^{20}$ Tamże, motyw 24: ,jeśli chodzi wreszcie o organizację przedsiębiorcy w zakresie jakości i środowiska naturalnego, dodatkowe punkty miały być przyznawane za spełnienie grupy kryteriów jakościowych oraz za program zachowania środowiska naturalnego potwierdzony uzyskaniem certyfikatu".

${ }^{21}$ Tamże, motyw 30.

${ }^{22}$ Tamże, motyw 46.

${ }^{23}$ Tamże, motyw 55.

${ }^{24}$ Tamże, motyw 86. 
Trybunał stwierdził, że kryteria oceny ofert mogą się odwoływać do aspektów ekologicznych, o ile ich stosowanie pozwala na obiektywną i przejrzystą ocenę ofert. Dodatkowo Trybunał potwierdził, że dla oceny dopuszczalności stosowania rozwiązań ukierunkowanych na realizację tzw. celów drugoplanowych nie ma znaczenia - co do zasady - czy rozwiązania te zapewnią realizację założonych celów ${ }^{25}$. Stanął mianowicie na stanowisku, że instytucje zamawiające mają znaczną swobodę w zakresie wyznaczania zarówno celów, które zamierzają osiągnąć poprzez udzielenie zamówienia, jak i doboru środków do ich realizacji. Swoboda ta podlega oczywiście pewnym ograniczeniom. Przede wszystkim unijne prawo zamówień publicznych wymaga $\mathrm{w}$ każdym przypadku przestrzegania zasady równego traktowania wykonawców oraz wypływających z niej zasad szczegółowych, w szczególności przejrzystości i obiektywizmu ${ }^{26}$.

Ograniczeniem swobody zamawiających jest również zasada proporcjonalności, która wymaga, aby stosowane rozwiązania nie były nadmierne. $\mathrm{Z}$ tego względu wspomniano wcześniej, że ocena zasadności przyjmowanych rozwiązań nie ma znaczenia „co do zasady”. W tym kontekście, w ramach rozważań nad koncepcją local content, warto przywołać również wyrok Trybunału z dnia 27 października $2005 \mathrm{r}$. w sprawie C-234/03 Contse SA, Vivisol Srl, Oxigen Salud SA przeciwko Instituto Nacional de Gestión Sanitaria (Ingesa), dotyczący organizowanego w Hiszpanii postępowania o udzielenie zamówienia na świadczenie usług terapii oddechowej, które wymagało m.in. dostarczania butli gazowych ze sprężonym tlenem. W orzeczeniu oceniano m.in. dopuszczalność promowania (poprzez przyznawanie dodatkowych punktów) wykonawców, którzy w chwili składania ofert posiadali co najmniej dwa zakłady produkcyjne wytwarzające tlen, położone w odległości mniejszej niż 1000 km od stolicy prowincji, w której zamówienie miało być realizowane. Ograniczenie obszaru uzasadniano bezpieczeństwem dostaw. W rezultacie jednak obszar spełniający te wymogi obejmował de facto terytoria Hiszpanii, Portugalii oraz część Francji, bez pozostałych państw członkowskich UE. Wobec tego Trybunał uznał, że „o ile bezpieczeństwo dostaw może być jednym z kryteriów branych pod uwage przy wyborze najkorzystniejszej ekonomicznie oferty w przypadku usług takich jak usługi rozważane w postępowaniu przed sądem krajowym, które to kryterium służy ochronie życia i zdrowia osób, jako że przewiduje ono zróżnicowaną produkcję własną w pobliżu miejsca konsumpcji [...], o tyle należy stwierdzić, że w niniejszej sprawie kryteria te nie wydają się pod wieloma względami dostosowane do zamierzonego celu"27. Trybunał zwrócił uwagę, że w sprawie nie przedstawiono dowodów potwierdzających zwiększone ryzyko opóźnienia dostaw tlenu. W rezultacie orzekł,

${ }^{25}$ Wyrok Trybunału z dnia 4 grudnia 2003 r. w sprawie C-448/01 EVN AG i Wienstrom GmbH przeciwko Republice Austrii, motyw 53.

${ }^{26}$ Tamże, motyw 33.

${ }^{27}$ Wyrok Trybunału z dnia 27 października 2005 r. w sprawie C-234/03 Contse SA, Vivisol Srl, Oxigen Salud SA przeciwko Instituto Nacional de Gestión Sanitaria (Ingesa), motyw 61. 
że chociaż „rząd hiszpański słusznie zauważa, iż wybór odległości i środka transportu jest uznaniowy, to jednak należy stwierdzić, że przyjęte w niniejszej sprawie kryterium $1000 \mathrm{~km}$ wydaje się niestosowne dla realizacji zamierzonego celu"28.

Podsumowując, należy stwierdzić, że w żadnej ze spraw rozstrzygniętych przywołanymi orzeczeniami nie powoływano się na koncepcję local content, niemniej każde z nich ma bardzo istotne znaczenie dla określenia prawnych uwarunkowań urzeczywistniania tej koncepcji w systemie zamówień publicznych. Wynikające z nich kluczowe wnioski można ująć w następujący sposób:

Po pierwsze funkcje zamówień publicznych nie ograniczają się wyłącznie do zaspokajania potrzeb czysto ekonomicznych, lecz mogą być wykorzystywane również do osiągania celów drugoplanowych, w szczególności o charakterze ekologicznym, społecznym, proinnowacyjnym czy odnoszącym się do wspierania MŚP.

Po drugie zamawiający ma swobodę w zakresie wyznaczania celów, które zamierza osiągnąć poprzez udzielenie zamówienia publicznego, ale także w zakresie doboru środków, które w jego ocenie pozwolą na optymalną realizację przyjętych celów.

Po trzecie wspomniane uprawnienia zamawiającego podlegają jednak pewnym ograniczeniom. Przede wszystkim niedopuszczalne jest korzystanie $\mathrm{z}$ nich $\mathrm{w}$ taki sposób, który prowadziłby do nieproporcjonalnego ograniczenia konkurencji w postępowaniu o udzielenie zamówienia publicznego. W szczególności za niezgodne z prawem unijnym mogłoby zostać uznane uprzywilejowane traktowanie określonych wykonawców lub ich kategorii, bez uzasadnienia opartego na wszechstronnej analizie obiektywnych potrzeb zamawiającego.

\section{Praktyczne aspekty realizacji koncepcji local content w systemie zamówień publicznych}

Przywołane orzeczenia nie tylko wyrażają stanowisko Trybunału w konkretnych sprawach, ale także wytyczają odpowiedni kierunek interpretacji przepisów krajowych. Można zatem stwierdzić, że w świetle prawa zamówień publicznych - zarówno unijnego, jak i polskiego - nie istnieją przeszkody, które a priori oraz w sposób nieusuwalny uniemożliwiałyby realizację założeń koncepcji local content w systemie zamówień publicznych. W obowiązujących przepisach ustanowiono przy tym instytucje jednoznacznie nawiązujące do tej koncepcji. Z polskiej perspektywy należy w tym kontekście wymienić przede wszystkim tzw. preferencje unijne, a więc wyjątkowe uprawnienie zamawiających sektorowych, przyznane im jednoznacznie na poziomie unijnym w ramach art. 85 ust. 2 dyrektywy 2014/25/UE. Rozwiązanie to do polskiego systemu prawnego wprowadza art. 393 ust. 1 pkt 4 ustawy

${ }^{28}$ Tamże, motyw 62. 
z dnia 11 września 2019 r. Prawo zamówień publicznych. Przepis ten stanowi, że zamawiający sektorowy, który udziela zamówienia na dostawy, może „odrzucić ofertę, w której udział produktów, w tym oprogramowania wykorzystywanego w wyposażeniu sieci telekomunikacyjnych pochodzących z państw członkowskich Unii Europejskiej, państw, z którymi Unia Europejska zawarła umowy o równym traktowaniu przedsiębiorców, lub państw, wobec których na mocy decyzji Rady stosuje się przepisy dyrektywy 2014/25/UE, nie przekracza 50\%”. Rozwiązanie to ma oczywiście wyjątkowy charakter, lecz niewątpliwie realizuje koncepcję local content w odniesieniu do obszaru gospodarczego UE.

Podobną funkcję mogą niekiedy spełniać tzw. zamówienia zastrzeżone. Są to zamówienia, o których udzielenie mogą się ubiegać wyłącznie wykonawcy mający status zakładu pracy chronionej, spółdzielnie socjalne oraz inni wykonawcy, których głównym celem działalności jest społeczna i zawodowa integracja osób społecznie marginalizowanych. Należą do nich m.in. osoby bezrobotne lub poszukujące pracy czy też osoby do 30. roku życia oraz po ukończeniu 50. roku życia, posiadające status osoby poszukującej pracy, bez zatrudnienia. Tym samym zamówienia zastrzeżone mogą być dla zamawiających instrumentem osiągania celów z zakresu lokalnej polityki społecznej. Należy jednak przyznać, że ze względu na specyfikę zamówień zastrzeżonych (ukierunkowanie na wsparcie osób społecznie marginalizowanych) zakres zastosowania tej instytucji jest ograniczony ${ }^{29}$.

Możliwość stosowania preferencji unijnych, a także zamówień zastrzeżonych przy spełnieniu ustawowych warunków, została jednoznacznie potwierdzona przez prawodawcę, co niewątpliwie ułatwia ich stosowanie. Należy jednak podkreślić, że koncepcja local content może być realizowana również na podstawie innych instytucji prawa zamówień publicznych. Z pewnością należą do nich warunki udziału w postępowaniu, podstawy wykluczenia, możliwość składania ofert częściowych, odpowiednie kształtowanie opisu przedmiotu zamówienia, a przede wszystkim kryteria oceny ofert. Niezależnie jednak od tego, z jakich instytucji będzie korzystał dany zamawiający, realizując założenia koncepcji local content, kluczowe znaczenie dla oceny ich dopuszczalności będzie miało zawsze wykazanie funkcjonalnych powiązań pomiędzy tymi konkretnymi rozwiązaniami a celami zamawiającego i jego obiektywnie uzasadnionymi potrzebami. Odwołując się do wcześniejszych przykładów, warto zwrócić uwagę, że w sprawie C-513/99 Concordia Bus Finland proekologiczne kryteria oceny uznano za zgodne z prawem unijnym, ponieważ Miasto Helsinki potrafiło przekonująco wykazać, że ich stosowanie nie ma na celu ograniczania konkurencji i uprzywilejowania konkretnych wykonawców, lecz służy realizacji celów polityki ekologicznej miasta. Z kolei w sprawie C-234/03 Contse...

${ }^{29}$ Potwierdza to również praktyka. Zgodnie $\mathrm{z}$ aktualnymi informacjami na temat funkcjonowania systemu zamówień publicznych w Polsce w roku 2019 udzielono jedynie 177 zamówień zastrzeżonych, o łącznej wartości 116273 188,66 zł - Urząd Zamówień Publicznych, Sprawozdanie o funkcjonowaniu systemu zamówień publicznych w 2019 r., Warszawa 2020, s. 50-51. 
potwierdzono wprawdzie możliwość formułowania wymagań i ograniczeń ukierunkowanych na ochronę życia i zdrowia osób z danego regionu, jednak konkretne rozwiązanie przyjęte przez Instituto Nacional de la Salud uznano za niedopuszczalne, ponieważ zamawiający ten nie był w stanie wykazać proporcjonalności uprzywilejowania wykonawców z Półwyspu Iberyjskiego.

Właśnie ten obowiązek jest niewątpliwie najpoważniejszym wzywaniem dla każdego zamawiającego, który dąży do osiągania celów koncepcji local content np. wspierania lokalnych MŚP - poprzez udzielanie zamówień publicznych. Wyzwaniu temu można sprostać poprzez wyraźne powiązanie konkretnych rozwiązań z obiektywnymi celami danego zamawiającego. Wniosek ten warto zobrazować konkretnym przykładem. Jako jeden ze stosowanych w praktyce sposobów oceny poziomu realizacji koncepcji local content często wskazuje się badanie poziomu wydatków dokonywanych przez wykonawcę zamówienia na rzecz lokalnych podwykonawców lub dostawców ${ }^{30}$. W związku z tym można wyobrazić sobie, że udzielając zamówienia publicznego, zamawiający sformułuje kryteria oceny ofert, które będą premiowały wykonawców deklarujących wyższy poziom udziału takich wydatków w oczekiwanym przez nich wynagrodzeniu. Wykazując zasadność i proporcjonalność takiego rozwiązania, zamawiający powinien pokazać, że promując podejmowanie współpracy z lokalnymi przedsiębiorcami, zaspokaja własny interes i realizuje założone cele, np. w zakresie polityki społecznej, ekologicznej czy gospodarczej. Podobnie jak Miasto Helsinki wskazywało, że zastosowane kryteria oceny ofert realizowały strategiczne cele jego polityki ekologicznej, tak $\mathrm{w}$ przywołanym przykładzie należałoby wykazać, że istotnym interesem zamawiającego jest stymulowanie współpracy z lokalnymi MŚP, a przez to realizacja jego strategicznych celów, takich jak choćby kreowanie lokalnego środowiska innowacyjnego i transfer wiedzy czy też skracanie łańcuchów dostaw i osiąganie w ten sposób korzyści ekologicznych.

Źródeł tychże celów zamawiający mogą upatrywać nie tylko w ciążących na nich ustawowych obowiązkach, ale również w dokumentach nienormatywnych takich jak w szczególności strategie rozwoju czy innego rodzaju dokumenty programowe. Wykazanie związku pomiędzy zidentyfikowanymi na ich podstawie celami a podejmowanymi działaniami umożliwiłoby również wykazanie proporcjonalności działań podejmowanych przez zamawiającego. Z perspektywy polskich zamawiających niewątpliwie pomocna może się okazać w tym kontekście polityka zakupowa państwa. Jest to przyjmowany przez Radę Ministrów dokument określający „priorytetowe działania Rzeczypospolitej Polskiej w obszarze zamówień publicznych, a także pożądany kierunek działań zamawiających w zakresie udzielanych zamówień, który obejmuje w szczególności zakup innowacyjnych lub zrównoważonych

${ }^{30}$ Analogiczne rozwiązania zob. np. w opracowaniu The Department of Trade, Industry and Competition, Republic of South Africa, Guidance Document for the Calculation of Local Content, http://www. thedtic.gov.za/wp-content/uploads/IP-guideline.pdf [dostęp: 15.05.2021], a także A. Roberts, B. Valpy, dz. cyt. 
produktów oraz usług" ${ }^{31}$. Jednakże podstaw dla realizowania koncepcji local content i wspierania lokalnych MŚP zamawiający mogą upatrywać również w innych dokumentach. Wśród nich na szczególną uwagę zasługują strategie odwołujące się do ochrony klimatu i transformacji energetycznej, a także rozwoju jednolitego rynku cyfrowego i innowacji. $Z$ jednej strony bowiem są one obecnie uznawane za podstawowe filary rozwoju Unii Europejskiej i jej państw członkowskich ${ }^{32}, \mathrm{z}$ drugiej zaś silnie jest $\mathrm{w}$ nich akcentowana potrzeba wykorzystywania potencjału zamówień publicznych, a także włączania MŚP w proces realizacji strategicznych celów ekologicznych i innowacyjnych. Tym samym dokumenty te mogą stanowić podstawę dla uzasadnienia realizacji założeń koncepcji local content poprzez powiązanie jej z innymi obiektywnymi celami polityki rozwoju, a przez to umożliwiają wykazanie proporcjonalności środków stosowanych dla ich urzeczywistnienia.

\section{Podsumowanie}

Na podstawie przeprowadzonych rozważań można przyjąć, że wykorzystywanie koncepcji local content $\mathrm{w}$ procesie udzielania zamówień publicznych może korzystnie wpływać na efektywność działalności zakupowej i inwestycyjnej zamawiających. Oczywiście będzie to możliwe pod pewnymi warunkami.

Po pierwsze należy zaznaczyć, że koncepcja local content w swym wąskim znaczeniu bywa postrzegana jako wyraz protekcjonizmu gospodarczego, który wyraża się w ustanawianiu rozwiązań faworyzujących przedsiębiorców krajowych względem ich zagranicznych konkurentów. Tego rodzaju podejście jest oczywiście nie do pogodzenia $\mathrm{z}$ unijnymi zasadami prawa zamówień publicznych, w szczególności z zasadą równego traktowania wykonawców, co zresztą nie powinno budzić wątpli-

${ }^{31}$ Art. 21 ust. 1 ustawy z dnia 11 września 2019 r. Prawo zamówień publicznych. W momencie opracowywania niniejszego tekstu polityka zakupowa państwa nie została jeszcze uchwalona.

${ }^{32}$ Znajduje to potwierdzenie w komunikatach Komisji Europejskiej pn. „Europejski Zielony Ład” (Komunikat Komisji do Parlamentu Europejskiego, Rady Europejskiej, Rady, Komitetu Ekonomiczno-Społecznego i Komitetu Regionów „Europejski Zielony Ład”, COM/2019/640) oraz „Nowa strategia przemysłowa dla Europy” (Komunikat Komisji do Parlamentu Europejskiego, Rady Europejskiej, Rady, Europejskiego Komitetu Ekonomiczno-Społecznego i Komitetu Regionów „Nowa strategia przemysłowa dla Europy", $\operatorname{COM}(2020) 102)$. Potwierdzają to również strategie i dokumenty programowe opracowywane na poziomie krajowym, do których z perspektywy polskiej należy zaliczyć przede wszystkim „Strategię na rzecz odpowiedzialnego rozwoju do roku 2020 (z perspektywą do 2030 r.)” (Uchwała nr 8 Rady Ministrów z dnia 14 lutego 2017 r. w sprawie przyjęcia Strategii na rzecz Odpowiedzialnego Rozwoju do roku 2020 (z perspektywą do 2030 r.), „Krajowy Plan Odbudowy i Zwiększania Odporności” (Warszawa 2021. Krajowy Plan jest związany z realizacją rozporządzenia Rady 2020/2094 z dnia 14 grudnia 2020 r. ustanawiającego Instrument Unii Europejskiej na rzecz Odbudowy w celu wsparcia odbudowy w następstwie kryzysu związanego z COVID-19), a także dokumenty sektorowe - „Plan Rozwoju Elektromobilności”, „Krajowe ramy polityki rozwoju infrastruktury paliw alternatywnych”, a także przyjęta w 2021 r. „Polityka Energetyczna Polski do 2040 r." (Obwieszczenie Ministra Klimatu i Środowiska z dnia 2 marca 2021 r. w sprawie polityki energetycznej państwa do 2040 r.). 
wości w kontekście wspomnianego na wstępie wyroku ws. C-243/89. Należy więc jednoznacznie stwierdzić, że preferowanie lokalnych, regionalnych lub krajowych rozwiązań lub wykonawców w postępowaniach o udzielenie zamówienia publicznego nie może być celem samym w sobie.

Analiza unijnego orzecznictwa prowadzi jednak do wniosku, że możliwe jest uwzględnienie założeń local content w charakterze celów drugoplanowych, zaspokajanych poprzez udzielenie zamówienia publicznego. Mianowicie dopuszczalne wydaje się ukształtowanie postępowania o udzielenie zamówienia publicznego w taki sposób, który pozwoli zamawiającemu nie tylko zaspokoić bezpośrednią korzyść ekonomiczną, ale także umożliwi odniesienie innych korzyści, które zamawiający spodziewał się uzyskać w odniesieniu do środowiska lokalnego, regionalnego czy też krajowego.

Wreszcie na zakończenie warto podkreślić, że podejście ukierunkowane na realizację koncepcji local content zasługuje na uwagę $\mathrm{z}$ jeszcze jednego powodu. Jego przyjęcie wymusza na zamawiających przyjmowanie holistycznej perspektywy, uwzględniającej szerszy kontekst podejmowanych działań. Obowiązek uzasadnienia decyzji o stosowaniu rozwiązań realizujących koncepcję local content i konieczność jej oparcia na obiektywnie uzasadnionych potrzebach zamawiającego skłania bowiem do poszukiwania powiązań pomiędzy działalnością zakupową i inwestycyjną a innymi obszarami aktywności zamawiających, a także strategicznymi celami polityki rozwoju. W ten sposób może z kolei się przyczyniać do zwiększenia spójności działań podmiotów publicznych (w szczególności administracji publicznej) $)^{33}$ i coraz silniej postulowanego zintegrowanego podejścia do realizacji strategicznych celów polityki rozwoju.

\section{Resumen extenso / Streszczenie}

El concepto de "local content" en el sistema de contratación pública

Aunque el concepto de local content [contenido local] ha ido ganando popularidad en el discurso económico internacional en los últimos años, parece imposible formular una definición precisa. Sin embargo, cabe suponer que su supuesto fundamental es iniciar las acciones dirigidas a la promoción de prestaciones - bienes y servicios ofrecidas por empresarios que operan a nivel local, es decir, en la región o el país del comprador. Tradicionalmente, el concepto de local content se percibía como una manifestación de las acciones proteccionistas adoptadas por los estados que,

${ }^{33}$ O potrzebie spójności działań służących realizacji strategicznych celów w obszarze energetyki i innowacji pisze w szczególności K. Kokocińska, Spójność działań organów władzy wykonawczej na rzecz rozwoju - na przykładzie sektora elektromobilności, w: Prawne i ekonomiczne aspekty rozwoju elektromobilności, red. K. Kokocińska, J. Kola, Warszawa 2019, s. 3-18. 
mediante un sistema de órdenes, prohibiciones o incentivos, intentaban favorecer a los empresarios locales frente a sus competidores extranjeros.

Normalmente, estas soluciones se aplican en países con un crecimiento económico dinámico, que al mismo tiempo se clasifican como los así llamados mercados emergentes o de reciente industrialización, como los así llamados países BRICS o muchos países de África. Sin embargo, en los últimos años, también en los países desarrollados está aumentando interés por las soluciones basadas en las suposiciones de local content. Sin embargo, no se basan en la limitación del acceso al mercado nacional a las entidades extranjeras, sino que están orientadas a la ejecución de objetivos estratégicos de la política de desarrollo de una determinada región o país, como si lo hicieran "aprovechando la ocasión" a la hora de realizar las actividades de inversión generalmente abiertas a la competencia internacional. Un ejemplo de este fenómeno, pueden ser, por ejemplo, las acciones emprendidas en muchos países europeos en el ámbito de las energías renovables. En concreto, declaran que las inversiones públicas que conciernen energía eólica se llevarán a cabo de la manera que garantice no sólo la consecución del objetivo primario en forma de desarrollo de las infraestructuras imprescindibles, sino también de los objetivos secundarios, como el fortalecimiento de la capacidad de innovación de las pequeñas y medianas empresas (pymes) locales, la modernización de la estructura profesional de la población que vive en las regiones donde se llevarán a cabo las inversiones y, por último, la mejora del entorno natural local.

Por otra parte, el enfoque basado en los supuestos del concepto de local content puede generar tensiones o incluso conflictos con los principios fundamentales del sistema legal de la Unión Europea, que incluyen la libertad de empresa y de prestación de servicios. Esto concierne en particular a las inversiones públicas mencionadas. En principio, estas inversiones se realizan en el marco de la legislación de la UE sobre contratación pública, cuya función principal es la protección de la competencia y la igualdad de trato de todos los contratistas. Por lo tanto, en este artículo se trata de responder a la pregunta de si la ejecución de los supuestos del concepto de local content (en su forma no proteccionista) se puede unir con los principios del derecho de la contratación pública.

En base al análisis de la jurisprudencia del Tribunal de Justicia de la UE, se ha establecido que no existen obstáculos a priori y de la manera inamovible imposibiliten la aplicación del concepto de local content en el sistema de contratación pública. Las sentencias en los asuntos C-513/99 Concordia Bus Finland, C-448/01 Wienstrom y C-234/03 Contse son de importancia clave en este contexto. En base a ellas se pueden formular las siguientes conclusiones clave:

- En primer lugar, las funciones de la contratación pública no se limitan únicamente a satisfacer necesidades puramente económicas, sino que también pueden utilizarse para alcanzar objetivos secundarios, en particular de carácter ecológico, social, pro-innovador o que se refieran al apoyo a las pymes. 
- En segundo lugar, el adjudicador tiene la libertad en el ámbito de fijar los objetivos que desea alcanzar a través de la adjudicación del contrato público, pero también en el ámbito de elección de los medios que, a su juicio, le permitan alcanzar de forma óptima los objetivos adoptados.

- En tercer lugar, sin embargo, las facultades mencionadas del adjudicador están sujetos a ciertas limitaciones. Ante todo, no es admisible ejercer esas facultades de manera que se produzca una restricción desproporcionada de la competencia en el procedimiento de contratación pública. En particular, el trato preferente a determinados operadores o a determinadas categorías de operadores sin una justificación basada en un análisis exhaustivo de las necesidades objetivas del adjudicador podría considerarse incompatible con la legislación de la UE.

En este contexto, la tarea clave del adjudicador, cuyo objetivo es desarrollar las actividades de compra o inversión teniendo en cuenta los supuestos del concepto de local content, es demostrar la relación entre los objetivos identificados y los beneficios esperados para el entorno local (económico, social o natural) y las acciones emprendidas. La realización de esta tarea también permitiría demostrar la proporcionalidad de las acciones emprendidas por el adjudicador y, en consecuencia, su conformidad con la ley de contratación pública. Vale la pena subrayar al mismo tiempo que emprender la propia tarea obliga a los adjudicadores a adoptar una perspectiva holística que tenga en cuenta el contexto más amplio de las acciones emprendidas, lo que en sí mismo debe valorarse positivamente. La obligación de justificar la decisión de utilizar soluciones que apliquen el concepto de local content y la necesidad de basar esta decisión en las necesidades objetivamente justificadas del adjudicador fomentan la búsqueda de vínculos entre las actividades de compra e inversión y otros ámbitos de la actividad de los adjudicadores, así como los objetivos estratégicos de la política de desarrollo. De este modo, puede contribuir a su vez a aumentar la coherencia entre las acciones de las entidades públicas (especialmente la administración pública) y el enfoque integrado cada vez más requerido para lograr los objetivos estratégicos de la política de desarrollo.

\section{Bibliografia}

Benedict Ch., Sekundärzwecke im Vergabeverfahren, Heidelberg 2000.

Chien K.-H., Pacing for Renewable Energy Development: The Developmental State in Taiwan's Offshore Wind Power, „Annals of the American Association of Geographers” 2020, vol. 110, iss. 3, pp. 793-807, DOI: 10.1080/24694452.2019.1630246.

Deringer H., Erixon F., Lamprecht Ph., Marel E. van der, The Economic Impact of Local Content Requirements: A Case Study of Heavy Vehicles, ECIPE Occasional Paper nr 1/2018.

Dyrektywa Parlamentu Europejskiego i Rady 2014/24/UE z dnia 26 lutego 2014 r. w sprawie zamówień publicznych, uchylająca dyrektywę 2004/18/WE, Dz. Urz. UE L 94/65. 
Hettne J., Strategic Use of Public Procurement - Limits and Opportunities, „European Policy Analysis” 2013, nr 7, s. 1-20.

Horubski K., Instrumentalizacja kryteriów oceny ofert, „Przegląd Prawa Publicznego” 2007, nr 11, s. $22-42$.

Industrial Strategy. Offshore Wind Sector Deal, 2019, https://www.gov.uk/government/publications/ offshore-wind-sector-deal [dostęp: 15.05.2021].

Kokocińska K., Spójność działań organów władzy wykonawczej na rzecz rozwoju - na przykładzie sektora elektromobilności, w: Prawne i ekonomiczne aspekty rozwoju elektromobilności, red. K. Kokocińska, J. Kola, Warszawa 2019, s. 3-18.

Kola J., Public Procurement as a Tool of Conducting Development Policy in Emerging Markets: The Example of Poland, w: Public Procurement Regulation in Africa: Development in Uncertain Times, Ed. G. Quinot, S. Williams-Elegbe, Durban - Johannesburg - Cape Town 2020, s. 249-269.

Komunikat Komisji z 11.12.2019 r. do Parlamentu Europejskiego, Rady Europejskiej, Rady, Komitetu Ekonomiczno-Społecznego i Komitetu Regionów „Europejski Zielony Ład”, COM(2019) 640 final.

Komunikat Komisji do Parlamentu Europejskiego, Rady Europejskiej, Rady, Europejskiego Komitetu Ekonomiczno-Społecznego i Komitetu Regionów „Nowa strategia przemysłowa dla Europy”, $\operatorname{COM}(2020) 102$ final, Bruksela, 10.03.2020.

Korinek J., Ramdoo I., Local content policies in mineral-exporting countries, OECD Trade Policy Papers nr 209/2017.

Kornecka A., Nowe farmy wiatrowe to impuls dla rozwoju gospodarczego, „Rzeczpospolita”, 21 kwietnia 2021 r., https://www.rp.pl/Opinie/304219898-Anna-Kornecka-Nowe-farmy-wiatrowe-to-impuls-dla-rozwoju-gospodarczego.html [dostęp: 1.05.2021].

UNCTAD, Local Content Requirements and the Green Economy. United Nations Conference on Trade and Development, Geneva 2014.

OECD, Local Content Requirements, OECD Trade Policy Brief, February 2019.

McCrudden Ch., Buying Social Justice: Equality, Government Procurement, \& Legal Change, Oxford 2007.

Ministerstwa Aktywów: Państwowych, Projekt ustawy o promowaniu wytwarzania energii elektrycznej w morskich farmach wiatrowych przekazany do konsultacji, https://www.gov.pl/web/ aktywa-panstwowe/projekt-ustawy-o-promowaniu-wytwarzania-energii-elektrycznej-w-morskich-farmach-wiatrowych-przekazany-do-konsultacji [dostęp: 1.05.2021].

Nwapi Ch., Defining the „Local” in Local Content Requirements in the Oil and Gas and Mining Sectors in Developing Countries, „Law and Development Review 2015, vol. 8, nr 1, s. 187-216.

Ovadia J.S., The Role of Local Content Policies in Natural Resources-based Development, Österreichische Forschungsstiftung für Internationale Entwicklung. Rohstoffe und Entwicklung, Wien 2015, s. $37-45$.

Roberts A., Valpy B., Methodology for Measuring the UK Content of UK Offshore Wind Farms, BVG Associates 2015, https://cdn.ymaws.com/www.renewableuk.com/resource/resmgr/Publications/Guides/uk_content_methodology.pdf [dostęp: 15.05.2021].

Social and Environmental Policies in EC Procurement Law. New Directives and New Directions, Eds. S. Arrowsmith, P. Kunzlik, Cambridge 2009.

Sołtysińska A., Instrumentalizacja zamówień publicznych - rozważania na tle unormowań prawa wspólnotowego, w: Studia z prawa Unii Europejskiej, red. S. Biernat, Kraków 2000, s. 373-385.

Sprawozdanie Komisji dla Parlamentu Europejskiego i Rady w sprawie barier w handlu i inwestycjach, $\operatorname{COM}(2020) 236$ final.

Stawiński M., Instrumentalizacja prawa zamówień publicznych w Unii Europejskiej w kontekście kryteriów oceny ofert, „Acta Universitatis Wratislaviensis - Przegląd Prawa i Administracji” 2016, t. 105 , s. $159-172$. 
Sturgeon T., Lima Chagas L., Barnes J., Inovar Auto: Evaluating Brazil's Automative Industrial Policy to Meet the Challenges of Global Value Chains, World Bank, Washington, D.C., 2017.

Sustainable Public Procurement under EU Law: New Perspectives on the State as Stakeholder, Ed. B. Sjåfjell, A. Wiesbrock, Cambridge 2015.

Szydło M., Prawna koncepcja zamówienia publicznego, Warszawa 2014.

The DTI, Guidance Document for the Calculation of Local Content, http://www.thedtic.gov.za/wp-content/uploads/IP-guideline.pdf [dostęp: 15.05.2021].

The Law of Green and Social Procurement in Europe, red. R. Caranta, M. Trybus, Copenhagen 2010.

Urząd Zamówień Publicznych, Sprawozdanie o funkcjonowaniu systemu zamówień publicznych w 2019 r., Warszawa 2020.

Ustawa z dnia 15 lutego 1933 r. o dostawach i robotach na rzecz Skarbu Państwa, samorządu oraz instytucyj prawa publicznego, Dz. U. $1933 \mathrm{nr} 19$ poz. 127.

Ustawa z dnia 10 czerwca 1994 r. o zamówieniach publicznych, Dz. U. 1994 nr 76 poz. 344. 